\title{
Metodologias Visuais na Investigação com Crianças / Visual Methodologies in Research with Children
}

https://doi.org/10.21814/uminho.ed.36.43

Jasmien Bougrine and Marijke Van Buggenhout Voicing Youth at Social Risk and Crime \& Society at the Vrije Universiteit Brussels, Belgium 



\section{Metodologias Visuais Na Investigação Com Crianças}

Métodos visuais, pesquisa visual ou metodologias baseadas em imagens abrangem o uso de materiais visuais no processo de investigação. Os métodos visuais têm sido comummente usados em vários estudos com a intenção de permitir que crianças e jovens comuniquem de maneiras que estão intimamente ligadas aos seus modos de vida e expressão (Stirling \& Yamanda-Rice, 2015). Recursos visuais - como imagens, vídeo, arte criativa e meios audiovisuais/baseados na web - podem fazer parte de diferentes estágios do processo de investigação e são usados para criar um caminho visual em direção à obtenção de dados ricos e para incluir participantes de forma mais ativa na pesquisa (Margolis \& Pauwels, 2011). Os métodos visuais podem ser integrados na recolha de dados e utilizados com outros métodos qualitativos, por exemplo, como técnicas visuais e material de elicitação na investigação narrativa ou na pesquisa etnográfica. Podem também ser usados ao estabelecer o desenho da investigação em colaboração com os participantes e funcionam como uma ferramenta no processo de interpretação dos dados. Além disso, os recursos visuais têm sido usados na produção de pesquisas e podem também ser usados para fins de divulgação em exposições, ensaios visuais, documentários e filmes.

O surgimento dos recursos visuais nos estudos da infância conheceu duas importantes evoluções ocorridas desde o início do século XX. Primeiro, aumentou uma maior consciência nos campos da sociologia, antropologia social e geografia para o facto de os recursos visuais não serem mais subjetivos ou objetivos do que o texto escrito (Pink, 2013). Segundo, o final do século $X X$ e o início do século $X X I$ trouxeram um interesse crescente nas experiências, representações e entendimentos das crianças, levando a mais investigações-com, em vez de investigações-sobre as crianças. Essa transição nos estudos da infância encapsulou um movimento no sentido de considerar as crianças como parceiros ativos, capazes e competentes na pesquisa. Fortalecido pela Convenção das Nações Unidas sobre os Direitos da Criança $(C D C)$, o direito à participação inspirou muitas abordagens dirigidas e centradas na criança, nas quais os investigadores repensam e refinam as suas práticas investigativas com crianças e jovens. Com a CDC cresceu a consciência de que os direitos das crianças também se aplicam aos processos de investigação, declarando explicitamente que as crianças devem ser estimu- 
ladas a escolher um método que permita a sua participação ativa no processo: "isso deve incluir liberdade de expressão. Este direito compreende a liberdade de procurar, receber e expandir informações e ideias de toda a espécie, sem consideração de fronteiras, sob forma oral, escrita, impressa ou artística ou por qualquer outro meio à escolha da criança" (CDC, Art. $\left.{ }^{\circ} 13,1\right)$. Consequentemente, os métodos visuais ganharam um lugar de destaque nos estudos da infância em todas as disciplinas, o que se reflete em várias edições especiais dedicadas aos métodos visuais e criativos e na existência de revistas especializadas e manuais sobre a temática. Métodos criativos e visuais geram oportunidades para tornar as experiências vividas "tangíveis" e "visíveis", transformando assim o material "desconhecido" e "não falado" em "sensorial" que pode ser usado em diferentes estágios do processo de investigação e representação, o que é especialmente interessante para investigação com crianças. As metodologias visuais podem, portanto, ser utilizadas como ferramentas para criar perceções de experiências mais profundas, emoções, conhecimentos subjetivos e questões da vida quotidiana de crianças e jovens.

Abordagens visuais na investigação, discussões teóricas e questões epistemológicas foram avaliadas e reavaliadas ao longo do tempo, bem como as formas e "maneiras" de aplicar métodos visuais na investigação. 0 meio mais comummente discutido naquelas abordagens tem sido a fotografia e o uso, criação e implementação de imagens. Particularmente comum em estudos de infância e pesquisa de desenvolvimento comunitário tem sido o uso de photovoice e métodos de foto-elicitação (em que as crianças recebem materiais visuais ou produzem suas próprias imagens e, posteriormente, são solicitadas a narrá-las). As fotografias em particular têm desempenhado um papel significativo na comunicação e no relato das experiências das crianças e do que consideram importante nas suas vidas. Além do material fotográfico, muitos outros exemplos de métodos visuais e criativos podem ser encontrados nos estudos da (primeira) infância. Desenhos, técnicas de classificação de imagens, autorretratos criativos, graffiti, colagem, filme e videografia, media e imagens em comunicações digitais e baseadas na web têm sido relatadas para criar espaços e novas dimensões e envolver as crianças na investigação.

Os recursos visuais podem ser incorporados em metodologias e abordagens já existentes, proporcionando assim, por exemplo, uma nova dimensão (visual) para projetos de pesquisa narrativa (cf. etnografia visual, narrativas visuais, narrativa visual e photovoice), pois são conhecidos por terem um efeito estimulante na construção de diálogos. Tem sido, ainda, defendido que 
a prática de investigação visual pode criar metodologias e pode promover novas maneiras de gerar, ter acesso e representar novos tipos de conhecimento (Pink, 2013).

Os recursos visuais são frequentemente incorporados em projetos de pesquisa participativa e podem servir como ferramentas para definir ou orientar agendas investigativas, cocriar conhecimento, interpretar e analisar dados. Essas pesquisas podem diminuir o desequilíbrio de poder entre o investigador e os participantes, e permitem que as crianças criem um sentido de propriedade e orientem a agenda investigativa. $\mathrm{O}$ uso de métodos visuais fornece maneiras alternativas de ajudar as crianças a elucidar as suas experiências e oferece um terreno fértil para mais agência e escolha nesse processo. Além disso, envolver as crianças com recursos visuais no processo de investigação, não só lhes fornece um meio alternativo de expressão, mas também pode oferecer diversão e emoção.

Embora os métodos visuais nos estudos da infância (e em outros campos) se tenham tornado mais sofisticados ao longo dos anos, não há consenso epistemológico sobre a abordagem científica, o valor e o lugar das dimensões visuais na investigação ou o papel visual documental, afetivo e analítico que pode ou deve ter no decurso da investigação. A investigação visual tem sido predominantemente considerada um complemento aos dados textuais (Fleer \& Ridgway, 2014), no entanto, foi afirmado que, "as imagens devem ser consideradas como um elemento igualmente significativo" e "em alguns projetos, o visual pode-se tornar mais importante do que as palavras faladas ou escritas, em outras, não" (Pink, 2013, p. 10). Portanto, uma abordagem criticamente reflexiva sobre os ambientes em que o conhecimento é produzido e o papel do visual neles, bem como uma reflexão sobre a relação entre teoria e métodos visuais é importante em qualquer projeto de investigação. Outra consideração importante pode ser formulada pelo lado social da investigação. Apesar das muitas vantagens de conduzir pesquisas visuais com crianças, nem sempre é fácil, nem recomendado. As metodologias visuais podem não ser interessantes para todos os participantes, algumas crianças podem, também, sentir-se incompetentes ou tímidas para criar ou compartilhar os seus recursos visuais. A investigação visual bem-sucedida depende muito da relação investigador-participante.

Os métodos visuais permitem que as crianças participem ativamente da investigação, como especialistas das suas próprias vidas. Pelo facto de serem métodos respeitadores das formas de comunicação das crianças, os recursos visuais podem ser mais acessíveis e compreensíveis para as crianças, e 
METODOLOGIAS VISUAIS NA INVESTIGAÇÃO COM CRIANÇAS / VISUAL METHODOLOGIES IN RESEARCH WITH CHILDREN

desta forma proporciona novas oportunidades em desenvolver investigações com elas.

\section{Visual Methodologies in Research with Children}

Visual methods, visual research or image-based methodologies encompass the use of visual materials in the research process. Visual methods have been commonly used in numerous studies to enable children and young people to express themselves in ways that are closely linked to their ways of life and means of expression (Stirling \& Yamanda-Rice, 2015). Audiovisual such as pictures, video, creative art and web-based/audio - visual media - can be part of different stages of the research process and are used to create a visual path towards rich data and to include participants more actively in the scientific endeavour (Margolis \& Pauwels, 2011). Visual methods can be embedded in data-collection and used along with other methods, such as visual techniques and elicitation material in qualitative inquiry (e.g. narrative, ethnographic or activist research). They can also be used when determining the research design in collaboration with participants and serve as a tool in the interpretation process of data. Further, visuals have been used in research output and they can even serve dissemination purposes in exhibitions, visual essays, documentaries and films.

The emergence of visuals in childhood studies has undergone two important evolutions since the early 20th century. Firstly, greater awareness grew in the fields of sociology, social anthropology and geography because visuals are no more subjective or objective than written text (Pink, 2013). Secondly, the end of the 20th and the beginning of the 21st century brought an increasing interest in children's experiences, representation and comprehension abilities leading to more research with instead of about children. This transition in childhood studies encapsulated a movement towards considering children as active, capable and competent partners in research. Strengthened by the United Nations Convention on the Rights of the Child (UNCRC), the right to participation inspired many child-led and child-centred approaches in which researchers rethink and refine their research practices with children and young people. The awareness that children's rights are applicable to research processes as well, grew with the UNCRC explicitly stating that children should be encouraged to choose a method that allows for their active participation in the process: "this shall include the freedom to seek, receive and impart information and ideas of all kinds, regardless of frontiers, either orally, in writing or in print, in the form of art, or through any other 
media of the child's choice" (UNCRC, Art. 13, 1). Consequently, visual methods have gained a prominent place in childhood studies across disciplines. This is reflected in several special issues dedicated to visual and creative methods and the existence of specialized journals and handbooks on the matter. Creative and visual methods generate opportunities to render lived experiences "tangible" and "visible", thereby transforming the "unknown" and "unspoken" to "sensory" material that can be used in different stages of the research process and representation. This is especially interesting for research with children. Visual methodologies can thus be used as tools to create insights into deeper experiences, emotions, subjective knowledge and issues which are part of the everyday life of children and young people.

Visual research approaches, theoretical discussions and epistemological questions as well as the forms and ways of applying visual methods in research, have been assessed over time. The most commonly discussed medium in visual research approaches has been photography and the use, creation and implementation of images. Particularly common in childhood studies and community development research has been the use of photo -voice and photo-elicitation methods (in which children are given visual materials, or produce their images and are later asked to comment on and narrate about them). Photographs, in particular, have played a significant role in communicating and reporting children's experiences, and showing what children consider to be important in their lives. Besides photographic material in research, many other examples of visual and creative methods can be found in (early) childhood studies. Drawings, picture sorting techniques, creative self-portraits, graffiti, collage, film and videography, media and visuals in digital and web-based communications, have all been seen to create new dimensions to engage children in research.

Visuals can be incorporated in already existing methodologies and approaches, so providing, for example, a new (visual) dimension to narrative research designs (cf. Visual ethnography, visual narratives, visual storytelling and photovoice) as they are known to have a stimulating effect on the construction of dialogue. Yet, it has been argued that visual research practice can create methodologies and open new ways to generate, access and represent new types of knowledge (Pink, 2013).

Visuals are often embedded in participatory research designs and can serve as tools to set or guide research agendas, co-create knowledge, interpret and analyse research data. Such research approaches can reduce the power imbalance between researcher and participants and enable children to 
create a sense of ownership and give them the power to direct the research agenda. The use of visual methods provides other ways to assist children to clarify and relate their experiences and offers the possibility for more agency and choice in this process. Furthermore, engaging children with visuals in the research process does not only provide children with another means of expression, but it can also offer a level of fun and excitement.

Even though visual methods in childhood studies (and elsewhere) have become more sophisticated over the years, there is no epistemological consensus on the scientific approach, value and place of visual dimensions in research, or the documentary, affective and analytical role that visuals can or should have in the course of scientific investigation. Visual research has predominantly been considered an addition to textual data (Fleer \& Ridgway, 2014); nevertheless, it has been stated that "images should be regarded as an equally meaningful element" and "in some projects, the visual may become more important than the spoken or written words, in others, it will not" (Pink, 2013, p. 10). A critically reflexive approach to knowledge production and the role of the visual therein, as well as a reflection on the relationship between theory and visual methods is beneficial to every research project. Another important consideration can be noted about the social side of research. Despite the many advantages of conducting visual research with children, it is not always easy, or recommended. Visual methodologies might not be interesting to all participants, while some children might also feel incompetent or timid in creating or sharing their visuals. Successful visual research is largely dependent on the researcher-participant relationship.

Visual methods enable children to participate in research more actively, as experts on their own lives. Because of the child-friendly approach, visuals can be more accessible and meaningful for children, enabling new opportunities in conducting research.

\section{Referências / References}

Fleer, M. \& Ridgway, A. (2014). Visual methodologies and digital tools for researching with young children: Transforming visuality. https://doi.org/10.1007/978-3-319-01469-2

Margolis, E. \& Pauwels, L. (2011). The SAGE Handbook of Visual Research Methods. https://doi. org/10.4135/9781412986502

Pink, S. (2013). Doing Visual Ethnography. London: Sage Publications.

Stirling, E. \& Yamanda-Rice, D. (2015). Visual Methods with Children and Young People. Academics and Visual Industries in Dialogue. Hampshire: Palgrave Macmillan. 